\section{Evaluation of Fruit Rot Resistance in Cucurbita Germplasm Resistant to Phytophthora capsici Crown Rot}

\author{
Charles S. Krasnow, Rachel P. Naegele, and Mary K. Hausbeck ${ }^{1}$ \\ Department of Plant, Soil, and Microbial Sciences, Michigan State \\ University, 612 Wilson Road, Room 140 Plant Biology Building, East \\ Lansing, MI 48824
}

Additional index words. ontogenetic, oomycete, pepo, Phytophthora capsici, squash

\begin{abstract}
Phytophthora blight is a destructive disease of cucurbits affecting the fruit, leaves, crown, and/or roots. Ten cucurbit PIs with known partial resistance to Phytophthora capsici root and crown rot were evaluated for resistance to Phytophthora fruit rot. Unwounded fruit from field-grown plants of Cucurbita moschata and $C$. pepo were inoculated in a controlled environment at 7 to 10 or 21 to 24 days post-pollination (dpp) with virulent $P$. capsici isolates to examine the effect of fruit age on disease development. Inoculated fruit were rated for lesion area and pathogen mycelial growth 7 days post-inoculation (dpi); fruit length, diameter, and pericarp thickness were also rated. Two $C$. pepo accessions (PI 169417 and PI 181761) had significant resistance to Phytophthora fruit rot at both 7 to $10 \mathrm{dpp}$ and 21 to $24 \mathrm{dpp}$. All accessions evaluated displayed reduced disease susceptibility as the fruit aged.
\end{abstract}

The oomycete plant pathogen Phytophthora capsici Leonian affects the cucurbit industry annually, in some cases causing $90 \%$ to $100 \%$ crop loss (Babadoost, 2000; Meyer and Hausbeck, 2012). Michigan is a leading producer of processing squash, pumpkins, and cucumbers in the United States with more than 68,500 acres of vegetable crops susceptible to P. capsici grown annually (Anonymous, 2013). In the midwest and eastern United States, $P$. capsici commonly causes a fruit rot on cucurbits and is a limiting factor in production (Babadoost, 2004; Hausbeck and Lamour, 2004; McGrath, 2000; Meyer and Hausbeck, 2012). Entire truck loads of processing squash, pumpkins, and cucumbers can be rejected at the processing facility as a result of the fruit becoming infected just before or during harvest and rotting during transit (Hausbeck and Lamour, 2004). The susceptibility of all commonly cultivated cucurbits (Cafe et al., 1995; McGrath, 2000) and the rapidity with which epidemics on squash and pumpkin fruit can develop make growers vulnerable. Specifically, in Michigan, fruit rot of processing cucurbits can be a major issue (Hausbeck and Lamour, 2004; Meyer and Hausbeck, 2012) as well as crown and root rots of squash and other vegetables (Hausbeck and Lamour, 2004; Meyer and Hausbeck, 2012; QuesadaOcampo and Hausbeck, 2010). Young fruit are especially susceptible during the first week after anthesis. Gevens et al. (2006) observed

\footnotetext{
Received for publication 28 Oct. 2013. Accepted for publication 7 Jan. 2014

We thank Amber Townes and Gabriel Torres for critically reviewing the manuscript and Adam Cortright for technical assistance.

${ }^{1}$ To whom reprint requests should be addressed; e-mail hausbec1@msu.edu.
}

in a detached fruit assay a high susceptibility to $P$. capsici in cucumber fruit within $7 \mathrm{dpp}$. Other researchers (Ando et al., 2009; Hausbeck and Lamour, 2004; Meyer and Hausbeck, 2012) noted that diverse cucurbit fruit including squash, pumpkin, melon, and cucumber were most susceptible to $P$. capsici at $3 \mathrm{dpp}$. Protecting the fruit throughout development is crucial but is difficult to achieve as a result of fungicide cost, a dense foliar canopy, and the long maturation time needed by some cucurbit cultivars. Depending on the nature of plant types (i.e., bush or vining), the fruit may lay directly on bare soil (Ando and Grumet, 2006), increasing the chances of $P$. capsici infection. Even when cucurbits are grown on black polyethylene plastic, vining cucurbit types will likely develop fruit along the vines that have trailed off of the plastic mulch. Although root and crown rot can be serious issues in certain cucurbit growing systems (CaféFilho and Duniway, 1995; Ristaino, 1991), fruit infection poses the most serious management challenge (Babadoost and Zitter, 2009).

Phytophthora capsici can survive in soil for 5 years or more through oospores in the absence of a susceptible host (Hausbeck and Lamour, 2004). This feature, along with the ability to produce large numbers of sporangia and zoospores in wet field conditions, is responsible for the pathogen's high infection potential. Control of $P$. capsici is not always sufficient with the use of traditional fungicide and cultural management practices. Growers of processing cucurbits (i.e., hard squash and pie pumpkins) are limited in cultural management options because the fruit are harvested mechanically and there is a relatively low profit margin. Therefore, raised plant beds, plastic mulch, and drip irrigation are not routinely used by growers of cucurbits for processing, although they are used with limited success by growers of cucurbits for the fresh market (Jackson et al., 2010). Fungicide use can be a limiting factor economically during seasons with high disease pressure as a result of the long maturity period of hard squash and pumpkins. In addition, the vining nature of the plants quickly cover the fields' surface making any sprays applied with a ground rig after the vines have filled in the rows difficult to achieve without damaging the crop. As a result of the difficulties encountered in managing $P$. capsici on processing cucurbits, alternative control methods have been sought.

Ontogenetic resistance (age-related resistance) is the ability of plants or plant organs to more aptly defend themselves against biotic and abiotic factors as they mature (Ficke et al., 2002). Cucurbit fruit develop resistance as they mature, and that resistance coincides with the completion of the fruit elongation phase, $\approx 1$ to 3 weeks after anthesis, depending on species (Ando et al., 2009; Gevens et al., 2006). This form of resistance to pathogen infection may provide an opportunity to improve fungicide application timing (Ando et al., 2009; Gadoury et al., 2003; Kim et al., 1989; Roberts et al., 2000). For example, age-related resistance in commercial pickling cucumbers has facilitated optimal timing of fungicide application during the crop's susceptible early growth stages. Fungicides are recommended to be applied when fruit are 1 inch, 3 inches, and 5 inches in length (Hausbeck and Lamour, 2004).

Identifying cucurbit accessions with Phytophthora fruit rot resistance to $P$. capsici would be a useful addition to cucurbit breeding programs attempting to integrate resistance into commercial varieties. Sources of root rot resistance have been identified and studied in wild cucurbit relatives (Chavez et al., 2011; Padley et al., 2008), and observations in the field indicate that commercial cucumber cultivars have tolerance to $P$. capsici root infection (Hausbeck and Lamour, 2004). However, fruit rot resistance has yet to be identified. Although fungicide and cultural management options have expanded, host resistance is especially desirable for low-input systems. The objectives of this study were 1) to identify resistance to fruit rot in wild germplasm previously identified as having crown/ root rot resistance; 2) to test ontogenetic fruit resistance to two P.capsici isolates 7 to 10 dpp and 21 to $24 \mathrm{dpp}$ in 10 C. moschata and C. pepo accessions; and 3 ) to determine if resistance correlates with changes in fruit size and pericarp thickness.

\section{Materials and Methods}

Plant material. Squash accessions were obtained from the U.S. Department of Agriculture Germplasm Resources Information Network (USDA-GRIN, <http://www.arsgrin.gov $>$ ). Four accessions were Cucurbita moschata and the remaining seven were Cucurbita pepo, including the control (Table $1)$. The accessions were chosen based on previous studies where crown and root rot resistance was demonstrated (Chavez et al., 
Table 1. Accessions and control fruit listed by species and country of origin.

\begin{tabular}{ll}
\hline Species and accession & Country of origin \\
\hline Cucurbita moschata & \\
PI 458740 & Paraguay \\
PI 442266 & Mexico \\
PI 442262 & Mexico \\
PI 634693 & India \\
& \\
Cucurbita pepo & \\
PI 169417 & Turkey \\
PI 615142 & Kazakhstan \\
PI 209783 & Germany \\
PI 512709 & Spain \\
PI 615132 & Mexico \\
PI 181761 & Lebanon \\
Table Ace & USA \\
\hline
\end{tabular}

2011; Meyer and Hausbeck, 2012; Padley et al., 2008). The commercial acorn squash cultivar Table Ace (C. pepo; Harris Seed Co., Rochester, NY) was used as the control (Enzenbacher and Hausbeck, 2012). Seeds of each accession were planted into 72-cell trays containing soilless peat mix (Suremix Michigan Grower Products Inc., Galesburg, MI) and grown for 4 weeks in a polyethylene greenhouse with a mean temperature of $22{ }^{\circ} \mathrm{C}$ $\left( \pm 4{ }^{\circ} \mathrm{C}\right)$. Up to 10 seedlings of each accession were transplanted into the field at the first true leaf stage into Capac loam (fine-loamy, mixed, active, mesic Aquic Glossudalfs) at the Michigan State University Plant Pathology Research Farm, East Lansing, MI. The field site had no history of $P$. capsic $i$ infestation and had been previously cropped to pumpkin. Plants were grown in raised beds covered with black polyethylene plastic and irrigated with trickle irrigation. Plant beds were $12.7 \mathrm{~cm}$ in height, spaced $91 \mathrm{~cm}$ apart, and plants were spaced $61 \mathrm{~cm}$ apart within beds. Plants were irrigated and fertilized according to local commercial standards. Once flowers reached anthesis, the female flowers were tagged and handpollinated. Squash fruit were harvested 7 to $10 \mathrm{dpp}$ or 21 to $24 \mathrm{dpp}$.

Isolates and inoculation. Two virulent $P$. capsici isolates were used in this study. Isolates were characterized by compatibility type (CT), mefenoxam sensitivity, and host (Lamour and Hausbeck, 2000). Isolate 12889 is an A1 CT, mefenoxam-resistant, and was isolated from pepper fruit. Isolate OP97 is also an A1 CT, mefenoxam-sensitive, and was isolated from pickling cucumber fruit. The isolates were obtained from the culture collection of Dr. Mary Hausbeck and were passed through pepper fruit before the study to ensure virulence. Throughout the study, the isolates were maintained on unclarified $\mathrm{V} 8$ juice agar ( $143 \mathrm{~mL}$ V8 juice, $3 \mathrm{~g} \mathrm{CaCO}_{3}, 16 \mathrm{~g}$ agar, $850 \mathrm{~mL}$ distilled water). The study was organized in a randomized design with three fruit forming a biological replicate, per isolate, per fruit age. The experiment was conducted three times. Two fruit were used as controls for each isolate by age replication. As a result of poor fruit set, PI 458740, PI 442262, and PI 634693 could not be inoculated with isolate 12889 .

Harvested fruit were washed in $10 \%$ bleach for $5 \mathrm{~min}$, rinsed with sterile distilled water, and allowed to dry under a laminar flow hood. Fruit were measured lengthwise from the peduncle to the blossom end and fruit circumference was measured at the greatest dimension of the fruit. A $1.2-\mathrm{cm}$ core was aseptically removed near the blossom end of each fruit using a sterile cork borer, and the pericarp thickness was measured (Naegele et al., 2013). A 7-mm plug of actively growing mycelia was placed $12.7 \mathrm{~cm}$ from the peduncle of the fruit and covered with a sterile screw cap (Axygen Inc., Union City, CA) using petroleum jelly as a fixative (Ando et al., 2009). Control cucurbits were inoculated with uncolonized V8 agar plugs. Fruit were then placed in clear plastic bins (Sterilite, Townsend, MA) lined with a moist paper towel and covered to maintain high relative humidity. The fruit were incubated at room temperature $\left(22 \pm 2{ }^{\circ} \mathrm{C}\right)$ under constant fluorescent light. 'Table Ace' squash were also used in a wounded fruit assay, in which fruit were punctured with a sterile pin before mycelial plug inoculation to determine the effect of wounding on disease incidence.

Disease assessment. After $7 \mathrm{dpi}$, the length and width of pathogen growth and water-soaked lesion on each fruit were measured to obtain the total affected area. Pathogen growth was rated based on mycelial growth and percentage of the fruit infected using a 0 to 4 scale adapted from Meyer and Hausbeck (2013) with $0=$ no visible pathogen growth, 1 = water soaking only, 2 = light visible mycelial growth, $3=$ moderate mycelial growth, $4=$ dense mycelial growth (Meyer and Hausbeck, 2013). After disease assessment, 1- to 2-mm sections removed from the margin of symptomatic fruit tissue were plated onto BARP $(0.05 \mathrm{~g}$ benomyl, $2 \mathrm{~mL}$ ampicillin, $2 \mathrm{~mL}$ rifampicin, and $0.1 \mathrm{~g}$ PCNB per liter)amended V8 agar plates. Recovered isolates were confirmed by pathogen morphology (Waterhouse, 1963) and mefenoxam sensitivity (Lamour and Hausbeck, 2000).

Statistical analysis. All analyses were completed using SAS Version 9.3 (SAS Institute, Cary, NC). Data were analyzed using analysis of variance. Fisher's least significant difference $(P=0.05)$ was used to measure differences between means. Significant accession-by-isolate interactions were measured using Proc Glimmix. Correlations between fruit age and pathogen growth rating were made using Pearson's correlation coefficient at $P=0.05$.

\section{Results}

Most fruit that were 7 to $10 \mathrm{dpp}$ when inoculated showed disease symptoms by $7 \mathrm{dpi}$ (Fig. 1). Symptoms including water soaking and external white mycelial growth characteristic of $P$. capsici were usually evident within $2 \mathrm{~d}$ (Fig. 2). Accessions with a mean rating value 1 or less were considered resistant $(\mathrm{R})$, and accessions with a mean value $1>\times<2.5$ were considered intermediately resistant (IR). Occasionally, only water soaking was present, but this occurred with a minority of the fruit. Some of the fruit developed a water-soaked appearance resulting from the permeation of the petroleum jelly. This was more often visible with the light skinned accessions, even at 21 to $24 \mathrm{dpp}$. This discoloration was confirmed negative for $P$. capsici using the isolation method described. Accessions PI 169417 and PI 181761 were significantly resistant $(P=0.05)$ to Phytophthora fruit rot at both 7 to 10 and 21 to $24 \mathrm{dpp}$. These two accessions showed consistent resistance to $P$. capsici 7 to $10 \mathrm{dpp}$ and were the only two which performed better than the control, 'Table Ace' (Table 2). The accession PI 512709 and 'Table Ace' showed intermediate resistance (rating less than 2.5) at 7 to $10 \mathrm{dpp}$. The four most resistant accessions in this study, PI 169417, PI 181761, PI 512709, and 'Table Ace', are all C. pepo species. Average pathogen growth ratings for $C$. moschata species (rating 3.4) and $C$. pepo species (rating 2.0) were significantly different at 7 to $10 \mathrm{dpp}(P<0.05)$.

Most accessions included in this study became significantly more resistant to $P$. capsici as they aged from 7 to 10 to 21 to $24 \mathrm{dpp}(P<0.05)$. Disease incidence was significantly greater at 7 to $10 \mathrm{dpp}$ than at 21 to $24 \mathrm{dpp}$ for each accession evaluated other than PI 169417 and PI 181761 (Table 2). All fruit were resistant to $P$. capsici (rating value of 1 or less) by 21 to $24 \mathrm{dpp}$. There was a negative correlation between pathogen growth

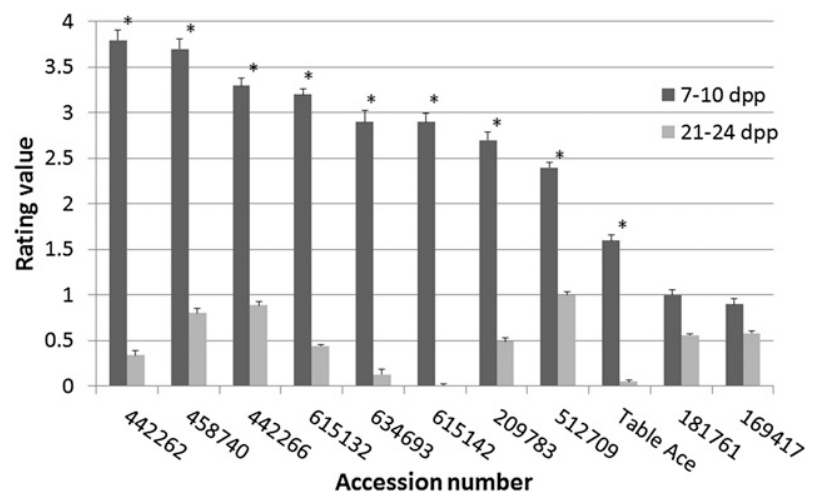

Fig. 1. Average Phytophthora fruit rot disease ratings for 10 accessions and the control based on assessment of pathogen growth. Average pathogen growth ratings based on a 0 to 4 scale. Error bars represent SEM. *Significant difference in rating between age ranges based on Fisher's least significant difference test $(P=0.05)$. 
and lesion size for all fruit tested from the 7 to 10 to 21 to $24 \mathrm{dpp}$ age range (Table 3 ). The negative correlation between pathogen growth and fruit age was highest in the four C. moschata accessions. Most accessions, with the exception of a single infected fruit each for PI 442266, PI 209783, and PI 512709, exhibited no symptoms of $P$. capsici when inoculated 21 to $24 \mathrm{dpp}$. Differences between the two isolates were not significant in this study $(P=0.295)$, and there were no significant differences between replications $(P=$ $0.883)$. Accession-by-isolate interactions were not significant $(P=0.313)$.

Morphologically, the fruit changed in size, thickness, and color as they matured

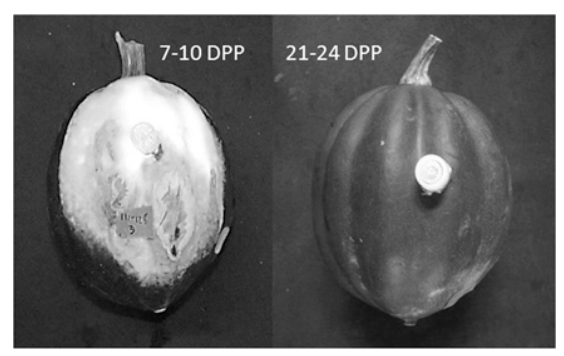

Fig. 2. Differences in susceptibility of acorn squash cv. Table Ace at 7 to 10 and 21 to 24 d postpollination (dpp). from 7 to $21 \mathrm{dpp}$ (Table 2). On average there was a 3-fold increase in squash fruit area from 7 to 10 to 21 to $24 \mathrm{dpp}$. There was no significant difference in pericarp thickness between species at the age ranges tested $(P=$ $0.737)$. In addition, pericarp thickness did not correlate with resistance $(P=0.124)$. Accessions PI 442262 and PI 512709 showed the largest increase in pericarp thickness as they aged from 7 to 10 to 21 to $24 \mathrm{dpp}$, whereas accession PI 209783 showed no increase between the two age ranges.

\section{Discussion}

An understanding of age-related resistance to $P$. capsici has the potential to reduce fungicide inputs and growers' costs. Previous studies have looked at many aspects of plant and fruit age-related resistance (ARR) (Gadoury et al., 2003; Gevens et al., 2006). Cucurbit powdery mildew ARR has been observed, and it was postulated that genes for resistance are activated or suppressed during plant growth (Kristkova and Lebeda, 1999). Age-related resistance has been noted in association with $P$. capsici infection of pepper and tomato plants (DeveleyRiviere and Galiana, 2007; Kim et al., 1989; Roberts et al., 2000). Pepper fruit also became increasingly resistant to $P$. capsici

Table 2. Mean pathogen growth ratings, proportion of fruit infected with Phytophthora capsici, and changes in fruit characteristics from 7 to 10 to 21 to $24 \mathrm{~d}$ post-pollination (dpp).

\begin{tabular}{|c|c|c|c|c|c|}
\hline Accession & $\begin{array}{l}\text { Growth } \\
\text { rating }^{z}\end{array}$ & Fruit infected & $\begin{array}{l}\text { Lesion size } \\
\text { (cm) }\end{array}$ & $\begin{array}{c}\text { Size increase } \\
(\%)^{y}\end{array}$ & $\begin{array}{c}\text { Pericarp } \\
\text { increase }(\%)^{x}\end{array}$ \\
\hline PI 442262 & $3.8 \mathrm{a}^{\mathrm{w}}$ & 0.82 & 12.69 & 398 & 125.0 \\
\hline PI 458740 & $3.7 \mathrm{a}$ & 0.73 & 11.06 & 194 & 69.2 \\
\hline PI 442266 & $3.3 \mathrm{ab}$ & 0.73 & 8.58 & 297 & 90.0 \\
\hline PI 615132 & $3.2 \mathrm{ab}$ & 0.69 & 11.21 & 66 & 39.2 \\
\hline PI 634693 & $2.9 \mathrm{ab}$ & 0.78 & 8.86 & 304 & 87.1 \\
\hline PI 615142 & $2.9 \mathrm{ab}$ & 0.54 & 9.64 & 114 & 61.7 \\
\hline PI 209783 & $2.7 \mathrm{abc}$ & 0.62 & 9.05 & 26 & 0.0 \\
\hline PI 512709 & $2.4 \mathrm{bc}$ & 0.41 & 6.22 & 178 & 98.9 \\
\hline Table Ace & $1.6 \mathrm{~cd}$ & 0.39 & 3.60 & 29 & 8.5 \\
\hline PI 181761 & $1.0 \mathrm{~d}$ & 0.09 & 3.35 & 60 & 29.3 \\
\hline PI 169417 & $0.9 \mathrm{~d}$ & 0.09 & 3.07 & 43 & 27.2 \\
\hline
\end{tabular}

${ }^{\mathrm{z}}$ Average growth rating, proportion of accessions infected with visible mycelium and lesion size $(\mathrm{cm})$ at 7 to $10 \mathrm{dpp}$.

${ }^{\mathrm{y}}$ Increase (\%) in fruit size from 7 to 10 to 21 to $24 \mathrm{dpp}$, calculated from average fruit area (length $\times$ diameter) differences between ages.

'Increase (\%) in pericarp thickness from 7 to 10 to 21 to $24 \mathrm{dpp}$.

wValues followed by the same letter are not significantly different based on Fisher's least significant difference test, $P=0.05$.

Table 3. Correlations between fruit age and disease assessments of Phytophthora fruit rot on 10 accessions and a commercial cultivar, Table Ace acorn squash.

\begin{tabular}{|c|c|c|c|c|}
\hline \multirow[b]{2}{*}{ Accession } & \multicolumn{2}{|c|}{ Lesion diam $(\mathrm{cm})$} & \multicolumn{2}{|c|}{ Pathogen growth rating } \\
\hline & $R^{2}$ & $P$ value & $R^{2}$ & $P$ value \\
\hline PI 442262 & -0.84 & 0.0007 & -0.96 & $<0.0001$ \\
\hline PI 458740 & -0.82 & 0.0002 & -0.88 & $<0.0001$ \\
\hline PI 442266 & -0.7 & 0.0004 & -0.83 & $<0.0001$ \\
\hline PI 615132 & -0.81 & $<0.0001$ & -0.81 & $<0.0001$ \\
\hline PI 634693 & -0.61 & 0.0215 & -0.82 & 0.0003 \\
\hline PI 615142 & -0.74 & $<0.0001$ & -0.79 & $<0.0001$ \\
\hline PI 209783 & -0.67 & 0.0017 & -0.71 & 0.0007 \\
\hline PI 512709 & -0.41 & 0.0318 & -0.48 & 0.017 \\
\hline Table Ace & -0.44 & 0.007 & -0.55 & 0.0006 \\
\hline PI 181761 & -0.34 & 0.0453 & -0.24 & 0.1541 \\
\hline PI 169417 & -0.28 & 0.1131 & -0.18 & 0.3125 \\
\hline
\end{tabular}

as they matured with resistance being positively correlated with an increase in cuticle thickness (Biles et al., 1993). In grapes, resistance to powdery mildew (Uncinula necator) occurs rapidly after fruit set, although the fruit are susceptible immediately after anthesis (Gadoury et al., 2003). The grape downy mildew pathogen, Plasmopara viticola, was found to be unable to penetrate the cuticle of grape fruit only after resistance became established 1 to 2 weeks post-bloom (Kennelly et al., 2005). Like with grapes and peppers, the resistance to $P$. capsici in mature cucurbits could be the result of physical factors in the exocarp, pericarp, or cuticle (Ando et al., 2009). In this study, we observed that 'Table Ace' (acorn squash) was more susceptible to $P$. capsici at 21 to $24 \mathrm{dpp}$ after being punctured with a $1 \mathrm{~mm}$ sterile needle with an average pathogen growth rating of 2.5 compared with a rating of 0.05 for nonwounded fruit (data not shown). This supports the idea that physical entry into the underlying tissue of mature fruit is one of the barriers for $P$. capsici. This effect has also been observed in peppers and cucumbers, where wounding fruit negated any observable ARR (Biles et al., 1993; Granke and Hausbeck, 2010). During the season, physical damage to the fruit's surface by mechanical damage, insects, rodents, or growth cracks could increase susceptibility to $P$. capsici of cucurbit cultivars that have acquired resistance (Enzenbacher and Hausbeck, 2012).

Age-related resistance to $P$. capsici was observed in most squash fruit tested in this study as they matured from 7 to 10 to 21 to 24 dpp. Pumpkins and squash reach maximum fruit size by 20 to $24 \mathrm{dpp}$ (Loy, 2004), and in this study, disease incidence at 21 to 24 dpp was less than $12.5 \%$ for all accessions tested with most accessions remaining healthy. This is consistent with previous work on ARR in cucumbers and other cucurbit fruit (Ando et al., 2009; Gevens et al., 2006; Meyer and Hausbeck, 2012), which demonstrated the transition from the end of the fruit elongation phase coinciding with the onset of resistance. In a recent study, the exocarp of two commonly grown processing cucurbits was found to become more dense as the fruit aged, which correlated with reduced Phytophthora fruit rot disease severity (Meyer and Hausbeck, 2012). In another study, a decrease in infection resulting from physical factors may have been observed with a hard-rinded pumpkin ( $C$. pepo) cultivar, which shows resistance to P. capsici (McGrath and Davey, 2007). The resistance observed may relate to the pathogen's ability to enter the fruit (Biles et al., 1993; Kennelly et al., 2005). In our study, however, pericarp thickness did not correlate with fruit resistance $(P=0.124)$, but thickness does not necessarily indicate firmness. Future studies could investigate how pericarp firmness and sugar accumulation affect pathogen growth, because Meyer et al. observed that exocarp firmness and fruit resistance increase with age in processing pumpkin (Meyer and Hausbeck, 2012). 
In addition to physical factors, there is the possibility of the presence of a biochemical factor in the outer surfaces of cucurbit fruit as was discussed for pepper fruit and the phytoalexin capsidiol (Hwang and Kim, 1990). This compound was present in greater amounts in the resistant pepper cultivars as well as the mature tissue and was associated with ARR in the pepper. Cucurbits are known to produce compounds that affect insect feeding (Tallamy, 1989) and the possibility of compounds that affect $P$. capsici opens another avenue for research. In addition, it would be useful to study the wounding effect observed in this study on other cultivars as well as fruit attached to a growing plant (Lau et al., 1986). Because processing squash are often infected in the field while laying on infested soil (Babadoost, 2000), observing these resistance mechanisms in the field using resistant and susceptible accessions would aid in better quantification of physical vs. biochemical resistance factors.

All accessions evaluated have shown resistance to Phytophthora root/crown rot (Chavez et al., 2011; Meyer and Hausbeck, 2012; Padley et al., 2008). However, based on our study, not all accessions were resistant to Phytophthora fruit rot. Our results agree with findings that show that fruit rot compared with other P. capsici blights must be considered separately (Sy and Bosland, 2006). The four $C$. moschata cultivars evaluated were susceptible to $P$. capsici fruit rot at 7 to $10 \mathrm{dpp}$ (greater than $73 \%$ infection) although these accessions have shown crown rot resistance in previous studies (Chavez et al., 2011; Padley et al., 2008). Resistance in the fruit most likely is conferred by different genes than those for root resistance (Sy and Bosland, 2006; Walker and Bosland, 1999), and the genes for all resistance mechanisms must be incorporated to have fully resistant cucurbit crops. This separation effect has also been seen in pepper, snap beans, and potato to Phytophthora spp. (Bonde et al., 1940; Gevens et al., 2006; Kim et al., 1989). The accessions with fruit rot resistance found in our study also exhibit crown and root rot resistance and may be a useful source of material for breeding. In addition to winter squash and pumpkins, breeding resistance into summer squash (C. pepo) would be useful in disease management. When temperatures are favorable during the harvest period, summer squash may be harvested daily, and the re-entry interval of many fungicides becomes prohibitive. Having cultivars available that contain genetic resistance to Phytophthora could enable growers to maintain a longer interval between fungicide sprays.

\section{Literature Cited}

Ando, K. and R. Grumet. 2006. Evaluation of altered cucumber plant architecture as a means to reduce Phytophthora capsici disease incidence on cucumber fruit. J. Amer. Soc. Hort. Sci. 131:491-498.

Ando, K., S. Hammar, and R. Grumet. 2009. Agerelated resistance of diverse cucurbit fruit to infection by Phytophthora capsici. J. Amer. Soc. Hort. Sci. 134:176-182.
Anonymous. 2013. Michigan Agricultural Statistics 2012-2013. U.S. Dept. Agr. Nat. Agric. Stat. Serv. 5 Feb. 2013. <http://www.nass.usda. gov/Statistics_by_State/Michigan/Publications/ Annual_Statistical_Bulletin/stats13/vegetables. pdf $>$.

Babadoost, M. 2000. Outbreak of Phytophthora foliar blight and fruit rot in processing pumpkin fields in Illinois. Plant Dis. 84:1345.

Babadoost, M. 2004. Phytophthora blight: A serious threat to cucurbit industries. APSnet Features. Apr.-May. doi: 10.1094/APSnetFeature2004-0404.

Babadoost, M. and T.A. Zitter. 2009. Fruit rots of pumpkin: A serious threat to the pumpkin industry. Plant Dis. 93:772-782.

Biles, C.L., M.M. Wall, M. Waugh, and H. Palmer. 1993. Relationship of Phytophthora fruit rot to fruit maturation and cuticle thickness of New Mexican-type peppers. Phytopathology 83:607611.

Bonde, R., F.J. Stevenson, and C.F. Clark. 1940 Resistance of certain potato varieties and seedling progenies to late blight in the tubers. Phytopathology 30:733-748.

Café-Filho, A.C., J.M. Duniway, and R.M. Davis. 1995. Effects of the frequency of furrow irrigation on root and fruit rots of squash caused by Phytophthora capsici. Plant Dis. 79:44-48.

Café-Filho, A. and J. Duniway. 1995. Effects of furrow irrigation schedules and host genotype on Phytophthora root rot of pepper. Plant Dis. 79:44-48.

Chavez, D.J., E.A. Kabelka, and J.X. Chaparro. 2011. Screening of Cucurbita moschata Duchesne germplasm for crown rot resistance to Floridian isolates of Phytophthora capsici Leonian. HortScience 46:536-540.

Develey-Riviere, M.P. and E. Galiana. 2007. Resistance to pathogens and host developmental stage: A multifaceted relationship within the plant kingdom. New Phytol. 175:405-416.

Enzenbacher, T.B. and M.K. Hausbeck. 2012. An evaluation of cucurbits for susceptibility to Cucurbitaceous and Solanaceous Phytophthora capsici isolates. Plant Dis. 96:1404-1414.

Ficke, A., D.M. Gadoury, and R.C. Seem. 2002. Ontogenic resistance and plant disease management: A case study of grape powdery mildew. Phytopathology 92:671-675.

Gadoury, D.M., R.C. Seem, A. Ficke, and W.F. Wilcox. 2003. Ontogenic resistance to powdery mildew in grape berries. Phytopathology 93:547-555.

Gevens, A.J., K. Ando, K.H. Lamour, R. Grumet, and M.K. Hausbeck. 2006. A detached cucumber fruit method to screen for resistance to Phytophthora capsici and effect of fruit age on susceptibility to infection. Plant Dis. 90:12761282.

Granke, L.L. and M.K. Hausbeck. 2010. Effects of temperature, concentration, age, and algaecides on Phytophthora capsici zoospore infectivity. Plant Dis. 94:54-60.

Hausbeck, M.K. and K.H. Lamour. 2004. Phytophthora capsici on vegetable crops: Research progress and management challenges. Plant Dis. $88: 1292-1303$.

Hwang, B.K. and Y.J. Kim. 1990. Capsidiol production in pepper plants associated with agerelated resistance to Phytophthora capsici. Korean Journal of Plant Pathology 6:193-200.

Jackson, K.L., J.F. Yin, A.S. Csinos, and P.S. Ji. 2010. Fungicidal activity of fluopicolide for suppression of Phytophthora capsici on squash. Crop Prot. 29:1421-1427.

Kennelly, M.M., D.M. Gadoury, W.F. Wilcox, P.A. Magarey, and R.C. Seem. 2005. Seasonal development of ontogenic resistance to downy mildew in grape berries and rachises. Phytopathology 95:1445-1452.

Kim, Y.J., B.K. Hwang, and K.W. Park. 1989. Expression of age-related resistance in pepper plants infected with Phytophthora capsici. Plant Dis. 73:745-747.

Kristkova, E. and A. Lebeda. 1999. Influence of developmental stage and plant habit of Cucurbita pepo L. genotypes on field resistance to cucurbit powdery mildew [in Czech]. Zahradnictvi 26:19-24 (Horticultural Science).

Lamour, K.H. and M.K. Hausbeck. 2000. Mefenoxam insensitivity and the sexual stage of Phytophthora capsici in Michigan cucurbit fields. Phytopathology 90:396-400.

Lau, O.L., Y. Liu, and S.F. Yang. 1986. Effects of fruit detachment on ethylene biosynthesis and loss of flesh firmness, skin color, and starch in ripening golden delicious apples. J. Amer. Soc. Hort. Sci. 111:731-734.

Loy, J.B. 2004. Morpho-physiological aspects of productivity and quality in squash and pumpkins (Cucurbita spp.). Crit. Rev. Plant Sci. 23:337-363.

McGrath, M.T. 2000. Phytophthora fruit rot. APSnet Feature. 15 Mar. 2013. <http://www. apsnet.org/publications/apsnetfeatures/Pages/ PhytophthoraFruitRot.aspx $>$.

McGrath, M.T. and J.F. Davey. 2007. Hard-rinded pumpkin cultivar evaluation for Phytophthora fruit rot. Plant Disease Management Reports 1:V125.

Meyer, M.D. and M.K. Hausbeck. 2012. Using cultural practices and cultivar resistance to manage Phytophthora crown rot on summer squash. HortScience 47:1080-1084.

Meyer, M.D. and M.K. Hausbeck. 2013. Agerelated resistance to Phytophthora fruit rot in 'Dickenson Field' processing pumpkin and 'Golden Delicious' winter squash fruit. Plant Dis. 97:446-452.

Naegele, R., T. Hill, H. Ashrafi, S. Reyes Chin-Wo, A. Van Deynze, and M.K. Hausbeck. 2013. QTL mapping of fruit rot resistance to the plant pathogen Phytophthora capsici Leonian in a recombinant inbred line Capsicum annuum L. population. Phytopathology

Padley, L.D.,, E.A. Kabelka, P.D. Roberts, and R. French. 2008. Evaluation of Cucurbita pepo accessions for crown rot resistance to isolates of Phytophthora capsici. HortScience 43:19961999.

Quesada-Ocampo, L.M. and M.K. Hausbeck. 2010. Resistance in tomato and wild relatives to crown and root rot caused by Phytophthora capsici. Phytopathology 100:619-627.

Ristaino, J.B. 1991. Influence of rainfall, drip irrigation, and inoculum density on the development of Phytophthora root and crown rot epidemics and yield in bell pepper. Phytopathology 81:922-929.

Roberts, P.D., R.R. Urs, and R.J. McGovern. 2000. Age and varietal response of tomato to infection by Phytophthora capsici. Phytopathology $90:$ S65.

Sy, O. and P.W. Bosland. 2006. Inheritance of Phytophthora stem blight, root rot, and foliar blight resistance in Capsicum. HortScience 41:1047-1047.

Tallamy, D.W.K.V.A. 1989. Variation and function of cucurbitacins in Cucurbita-An examination of current hypotheses. Amer. Nat. 133:766-786.

Walker, S.J. and P.W. Bosland. 1999. Inheritance of Phytophthora root rot and foliar blight resistance in pepper. J. Amer. Soc. Hort. Sci. 124:14-18.

Waterhouse, G.M. 1963. Key to the species of Phytophthora de Bary. Mycol. Pap. 92:1-22. 